\title{
KONCEPCJA OCENY JAKOŚCI PROGRAMÓW KSZTAŁCENIA
}

\author{
Andrzej Pacana \\ Politechnika Rzeszowska \\ Wydział Budowy Maszyn i Lotnictwa \\ Artur Woźny \\ Politechnika Rzeszowska \\ Wydział Zarządzania \\ Anna Sobczyńska \\ Politechnika Rzeszowska \\ Biuro ds. Jakości Kształcenia
}

\begin{abstract}
Streszczenie: Wysoka jakość procesu kształcenia jest wartością pożądaną na każdej uczelni wyższej. Właściwe programy kształcenia zwiększają prawdopodobieństwo osiągania przez studentów założonych efektów kształcenia. Te z kolei zwiększają szansę absolwentów na satysfakcjonującą pracę i karierę zawodową. Żeby programy kształcenia spełniały tę rolę i odpowiadały wciąż zmieniającemu się otoczeniu, należy je doskonalić. Aby ustalić kierunki doskonalenia, należy wcześniej dokonać przeglądu tych programów. Sam przegląd kończy się najczęściej alternatywną oceną podsumowującą. Celowym jest wprowadzenie liczbowej oceny jakości programu. W opracowaniu ocenę tę zaproponowano przeprowadzić metodą punktacji sformalizowanej.
\end{abstract}

Słowa kluczowe: program kształcenia, punktacja sformalizowana, jakość kształcenia

DOI: 10.17512/znpcz.2016.2.23

\section{Wprowadzenie}

Proces kształcenia w uczelniach wyższych jest weryfikowany poprzez pracowników uczelni, komisje akredytujące, a także poprzez wprowadzone elementy Deklaracji Bolońskiej, wdrożone systemy zarządzania jakością ISO 9001, IWA2, CAF czy Krajowe Ramy Kwalifikacji. Wprowadzenie Krajowych Ram Kwalifikacji do szkolnictwa wyższego w Polsce wydaje się być bardzo korzystne dla naszego kraju. Nie powinno być taktowane jako decyzja wynikająca z konieczności podporządkowania się Unii Europejskiej. Należy mieć na uwadze fakt, że żadne zalecenia czy ustalenia na poziomie europejskim, związane z Procesem Bolońskim czy decyzjami organów Unii Europejskiej, nie obowiązują żadnego kraju pozaeuropejskiego.

Najczęściej podaje się trzy główne powody, dla których kraje Unii Europejskiej oraz znaczna liczba krajów spoza Wspólnoty zdecydowały się kształtować jakość swojego szkolnictwa wyższego na krajowych ramach kwalifikacji (Kraśniewski b.r.):

- Pierwszym z tych powodów jest rosnąca mobilność obywateli UE. Dotyczy to zarówno mobilności studentów, ale także i mobilności absolwentów uczelni i szkół innych typów na europejskim rynku pracy. 
- Drugim istotnym powodem stosowania ram kwalifikacji jest coraz wyraźniej rysująca się potrzeba uwzględnienia perspektywy uczenia się przez całe życie. Ciągłe kształcenie powodować będzie konieczność wielokrotnego powrotu wielu osób (absolwentów) do systemu edukacji, w celu poszerzenia (ewentualnie wzbogacenia) swoich kwalifikacji.

- Trzecim ważnym powodem jest umasowienie w Polsce kształcenia na poziomie wyższym - w ostatnich latach liczba studentów wzrosła niemal pięciokrotnie; obecnie więcej niż co drugi młody człowiek w wieku od 19 do 24 lat studiuje. Jest to zmiana znacząca, zważywszy, że jeszcze niedawno studiowało zaledwie około $10 \%$ najzdolniejszych młodych ludzi z każdego rocznika. Zjawisko to, niezwykle pochlebnie komentowane w świecie, ma swoje istotne konsekwencje dla procesu kształcenia i jego rezultatów. Realizacja procesu kształcenia w poprzedniej formule - tak, jakby się nic nie zmieniło - nie doprowadzi do oczekiwanych wyników.

Istotne są w tym działaniu dwa występujące łącznie elementy: programy kształcenia i efekty kształcenia. Program kształcenia to opis określonych przez uczelnię spójnych efektów kształcenia, zgodny z Krajowymi Ramami Kwalifikacji dla Szkolnictwa Wyższego, oraz opis procesu kształcenia, prowadzącego do osiągnięcia tych efektów, wraz z przypisanymi do poszczególnych modułów tego procesu punktami ECTS. Wspomniane w definicji programów kształcenia efekty nauczania, rozumiane jako zasób wiedzy, umiejętności i kompetencji społecznych uzyskanych w procesie kształcenia przez osobę uczącą się, powinny być traktowane jako nadrzędne wobec programu studiów. Program studiów, obejmujący m.in. plan studiów i opis poszczególnych modułów kształcenia, powinien być tworzony w oparciu o uprzednio zdefiniowane efekty kształcenia. Działania na rzecz jakości kształcenia są niezwykle istotne, z punktu widzenia prowadzonych procesów dydaktycznych, które nieco inaczej wyglądają na studiach stacjonarnych, niestacjonarnych, doktoranckich czy podyplomowych. Aby ewentualnym problemom związanym z jakością kształcenia stawić czoło, trzeba obiektywnie ocenić aktualny sposób realizacji programów kształcenia (Pacana, Ostasz 2015, s. 146-157). Stąd jednym z zadań jednostki prowadzącej studia jest stosowanie odpowiednich mechanizmów (procedur) oceny, czy i w jakim stopniu założone efekty kształcenia są osiągane. Ocenę taką można wykonać w różny sposób. Częstym przypadkiem jest przegląd i ocena programów kształcenia, która powinna objąc dwa podstawowe elementy programu kształcenia, tj. efekty kształcenia i proces kształcenia prowadzący do uzyskania tych efektów. Odbywa się ona zwyczajowo po zakończonym roku akademickim i łączona jest $\mathrm{z}$ weryfikacją zakładanych efektów kształcenia w wybranych modułach kształcenia analizowanego programu (ZatwarnickaMadura 2011). Stosowane często oceny opisowe i opisowe podsumowania nie pozwalają na konkretną ocenę liczbową planów kształcenia. Nie dają również możliwości porównywania jakości planów. Rozwiązaniem może być tutaj wprowadzenie oceny liczbowej planów kształcenia. Ocenę taką można poprowadzić np. z wykorzystaniem zasad stosowanych przy ocenie zwanej punktacją sformalizowaną. Zastosowanie tej metody pozwoliłoby na zrealizowanie celu opracowania, jakim jest stworzenie koncepcji liczbowej oceny programów kształcenia. 


\section{Projekt arkusza przeglądu programu kształcenia}

Do stworzenia koncepcji oceny planu kształcenia wybrano druk „Roczny raport z przeglądu programu kształcenia i weryfikacji zakładanych efektów kształcenia" stosowany w Politechnice Rzeszowskiej (Polska). Raport ten w skróconej wersji zaprezentowano na Rysunku 1.

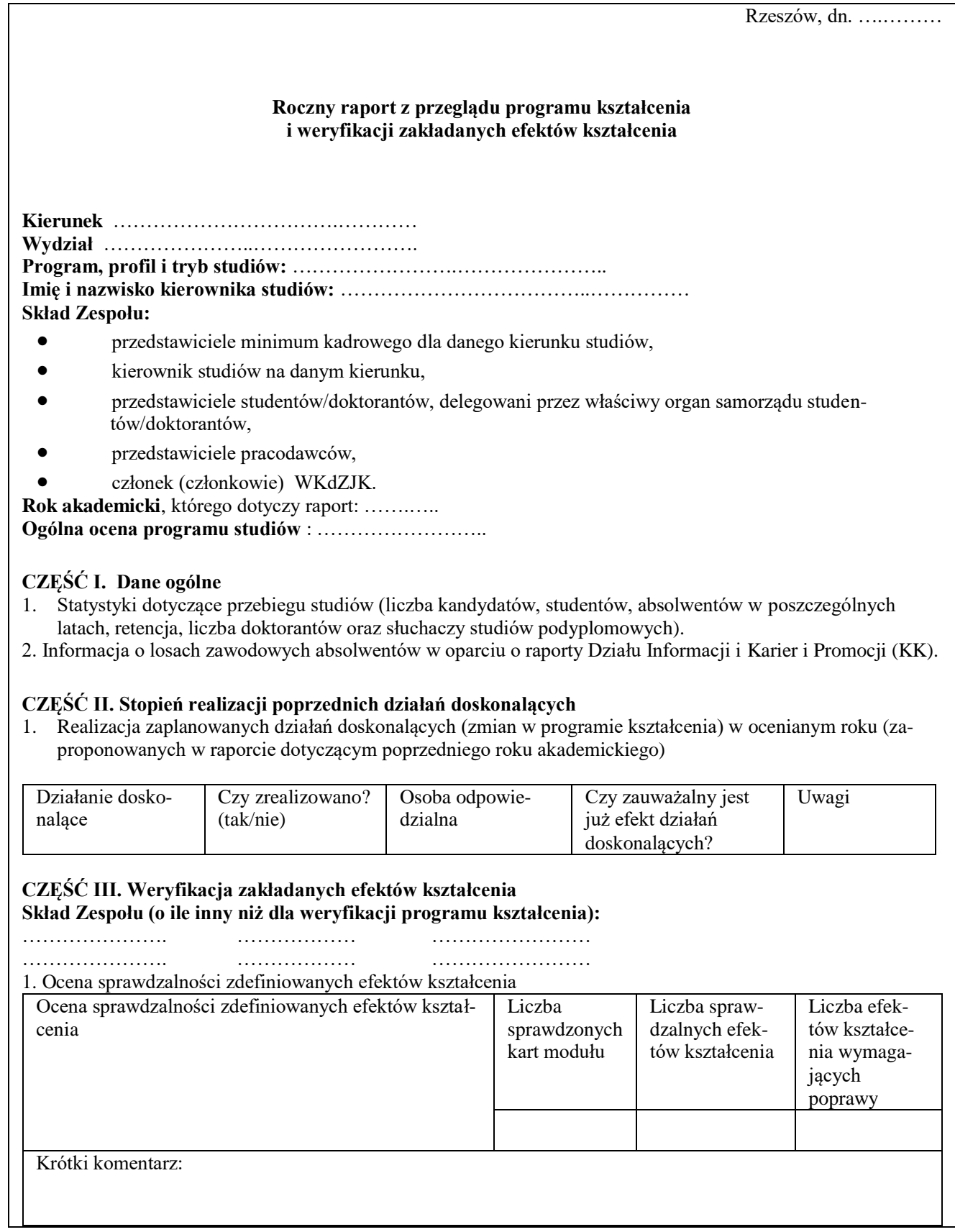




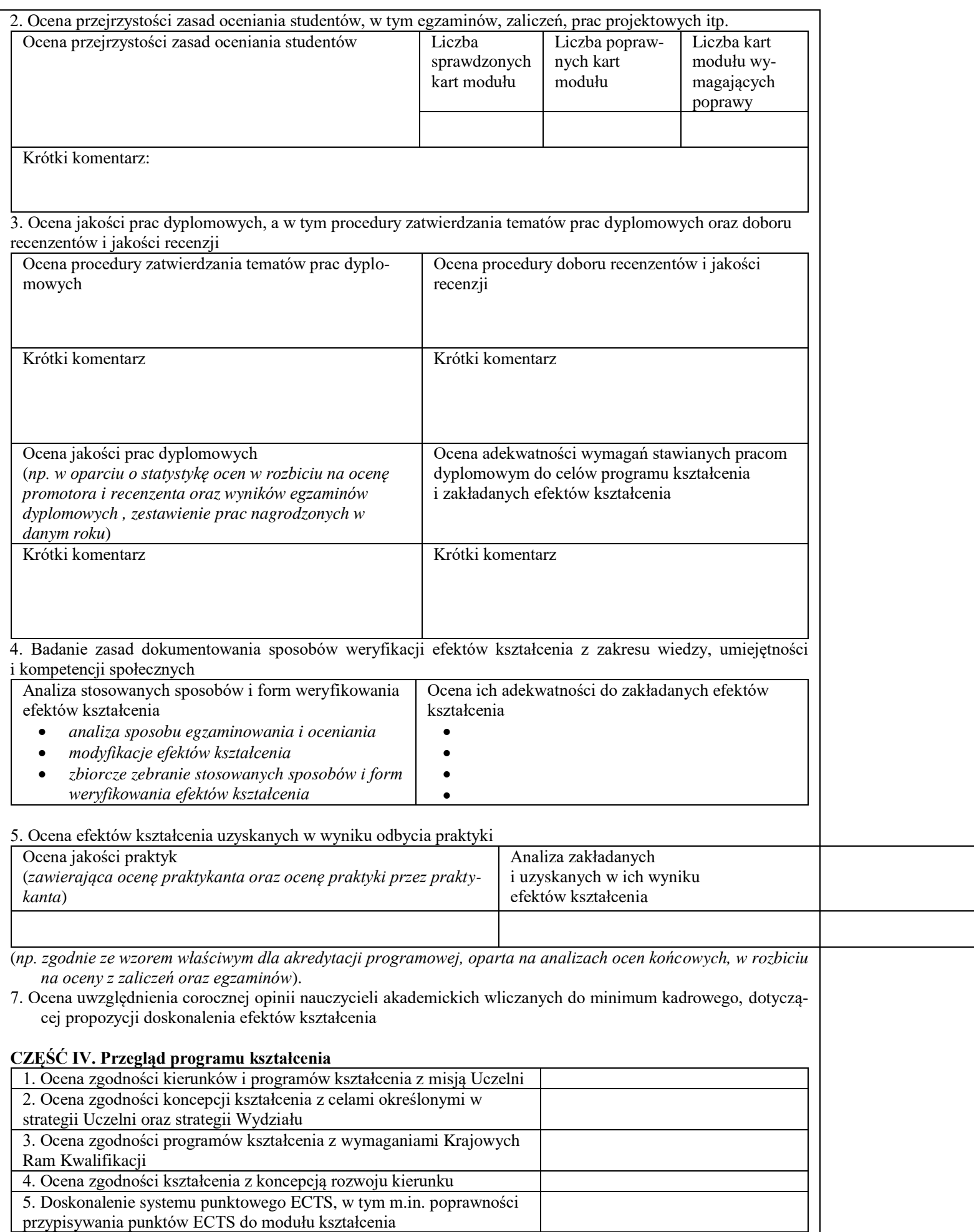




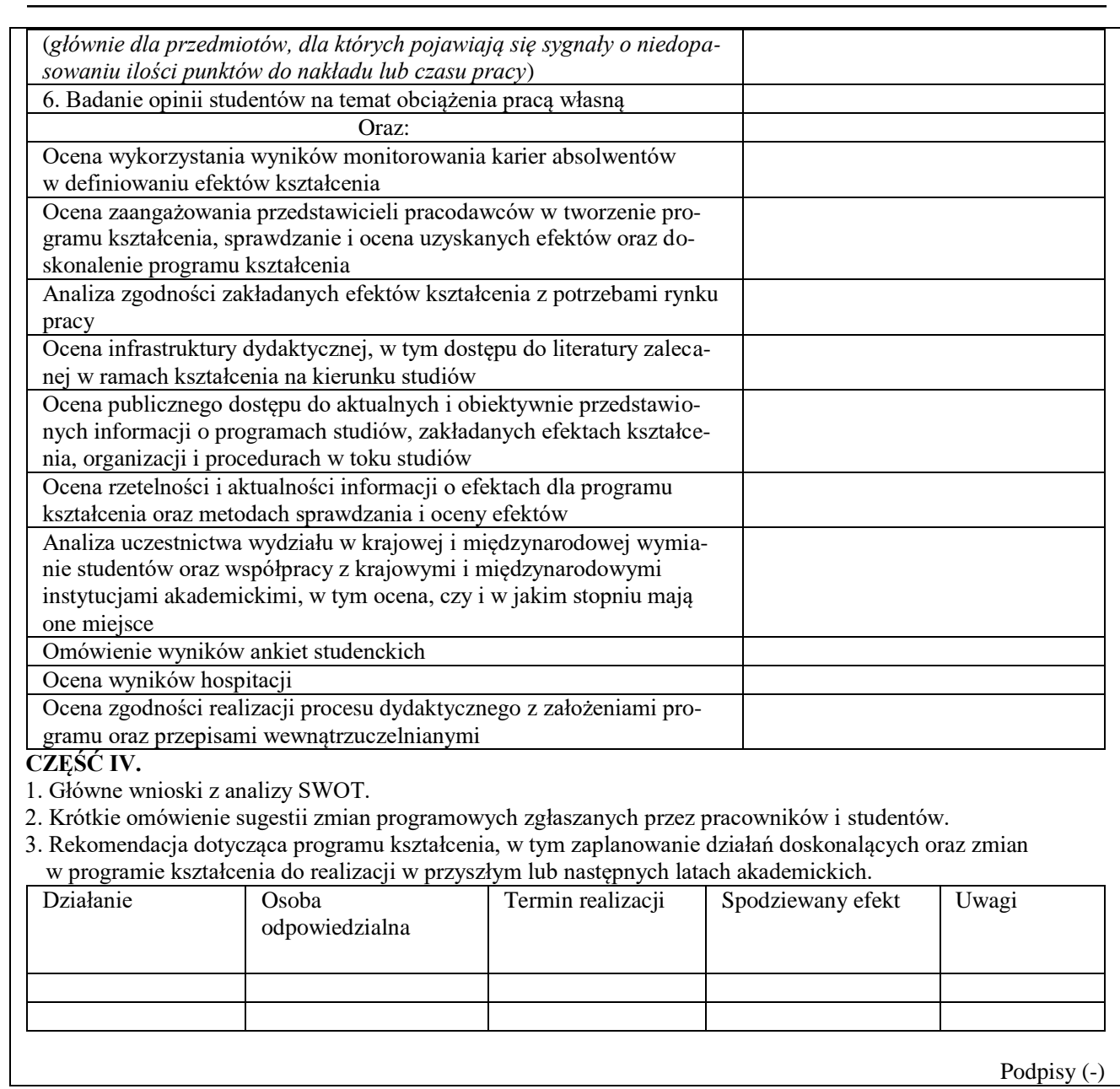

Rysunek 1. Fragment druku „Roczny raport z przeglądu programu kształcenia i weryfikacji zakładanych efektów kształcenia"

Źródło: Opracowanie własne

Na rysunku tym pominięto niewielką ilość informacji, które bezpośrednio nie są związane z przeglądem programów kształcenia. Pozostałe informacje w proponowanej koncepcji należałoby poddać ocenie punktowej, zgodnie z metodyką punktacji sformalizowanej.

\section{Punktacja sformalizowana}

Skuteczne zarządzanie jakością procesu kształcenia bardzo często wymaga określenia, czy podejmowane działania przekładają się na zwiększenie poziomu jakości (Zimon 2015, s. 551-564). Prowadzącym analizy jakości często nie wystarcza wskazanie, czy oceniany element jest dobry, czy zły. Takie określenie jest mało precyzyjne, a niekiedy wręcz dezinformujące. Stąd też stosuje się i ciągle do- 
skonali metody liczbowego określenia jakości. Słuszne bowiem jest stwierdzenie, że jeżeli czegoś nie potrafi się określić liczbowo, to znaczy, że to coś zbyt mało znamy. Zagadnienia te są przedmiotem szerokiego zainteresowania i obecnie istnieje kilkanaście podstawowych metod liczbowego określania poziomu jakości wyrobów. Samo obliczenie poziomu jakości, czyli skorzystanie z gotowych procedur obliczeniowych, nie nastręcza więc kłopotu.

Metoda punktacji sformalizowanej może być realizowana w dwóch wariantach:

- zwykłym: ocena stanów kryteriów jest dokonywana według uznania oceniającego;

- uwarunkowanym: ocena stanów kryteriów nie jest dowolna, lecz zależy od ściśle określonych warunków - kryterialny wzorzec jakości.

Gradacja ocen w punktacji sformalizowanej może być różna, np. dwu-, trzy-, pięcio- i dziesięciostopniowa. Ważnym jest, aby liczba punktów dla każdego stopnia była stała (wcześniej ustalona). W przypadku punktacji sformalizowanej literatura (Sęp, Perłowski, Pacana 2006) zaleca stosowanie pięciostopniowej skali ocen gradacja pięciostopniowa i punktacja: 1 (najgorzej) $\div 5$ (najlepiej).

Przy takim stopniowaniu ocen wzór na obliczanie poziomu jakości wyrobu wygląda następująco (Sęp, Perłowski, Pacana 2006):

$$
H=G+K-C
$$

Człon główny $G$ obliczany jest:

$$
G=\frac{R}{8 \cdot n}
$$

gdzie:

$$
R=(9 \cdot a+7 \cdot b+4 \cdot c+2 \cdot d+e-n)
$$

Człon korekcyjny oznaczony literą $K$ wyliczany jest ze wzoru:

$$
K=\frac{c+5 \cdot d+10 \cdot e}{200 \cdot n}
$$

Dla wymagań normalnych stała $C=0,05$, a dla wymagań zaostrzonych $C=0,1$.

Pozostałe oznaczenia we wzorach (1) $\div(4)$ :

$n$ - liczba rozpatrywanych kryteriów,

$a$ - liczba przyznanych ocen 5-punktowych,

$b$ - liczba przyznanych ocen 4-punktowych,

$c$ - liczba przyznanych ocen 3-punktowych,

$d$ - liczba przyznanych ocen 2-punktowych,

$e$ - liczba przyznanych ocen 1-punktowych.

W przypadku dokumentowania można stosować w tej metodzie następujący zapis:

$$
H=0, \ldots\left(a+b+c+d+e / n_{e}-n_{d}-n_{c}\right) K
$$


gdzie: $0, \ldots-$ poziom jakości wyrażony ułamkiem dziesiętnym,

$K$ - klasa jakości liczona ze wzoru:

$$
K=10-(10 \cdot q+y)
$$

gdzie: $q$ - jakość wyrażona ułamkiem dziesiętnym,

$y$ - liczba z przedziału $0 \div 1$ dopełniająca wartość w nawiasie ze wzoru (6), do najbliższej, większej liczby całkowitej,

$a \div e-$ liczby przyznanych ocen,

$n_{e}, n_{d}, n_{c}$ - numery kryteriów zaniżających jakość, zakwalifikowane odpowiednio do grupy o ocenie najniższej, niskiej i średniej.

Do wykonania obliczeń uproszczonych można stosować wzór na poziom jakości wyrobu:

$$
H_{u}=\frac{P}{P_{\max }}-C
$$

gdzie: $P$ - liczba punktów uzyskana przez wyrób według dowolnej gradacji ocen,

$P_{\max }-$ liczba punktów możliwa do zdobycia przy danej gradacji ocen,

$C=0,05-$ stała dla odbiorów normalnych,

$C=0,1-$ stała dla odbiorów zaostrzonych.

W przypadku zastosowania wzoru (7) metodę nazywa się punktacją uproszczoną (PU). Przebieg postępowania w przypadku metody PS i PU jest następujący:

1. Wybór kryteriów jakości, które będą podlegały ocenie.

2. Ocena punktowa kryteriów jakości.

3. Obliczanie wartości członu głównego oraz korekcyjnego.

4. Dobranie wartości stałej $C$.

5. Obliczenie poziomu jakości wyrobu i interpretacja wyniku.

Stosując zarówno metodę PS, jak i PU dla porównania względem obliczonego już innymi metodami poziomu jakości, można (dla uniknięcia konieczności ponownej oceny kryteriów opartej na przyznawanych punktach, które wcześniej oceniane były w skali $0 \div 1$ ) zastosować równoważności przedstawione w Tabeli 1 .

Tabela 1. Zależność ilości przyznanych punktów od jakości kryterium

\begin{tabular}{|c|c|}
\hline Jakość kryterium & Ocena punktowa (liczba punktów) \\
\hline Od 0 do 0,2 włącznie & 1 \\
\hline Od 0,2 do 0,4 włącznie & 2 \\
\hline Od 0,4 do 0,6 włącznie & 3 \\
\hline Od 0,6 do 0,8 włącznie & 4 \\
\hline Od 0,8 do 1,0 włącznie & 5 \\
\hline
\end{tabular}

Źródło: Opracowanie własne 


\section{Ocena programu kształcenia}

Do liczbowej oceny jakości programu kształcenia wykorzystać można Tabelę 2.

Tabela 2. Przykładowe kryteria oceny programu ksztalcenia

\begin{tabular}{|c|c|c|c|c|c|}
\hline Kryterium oceny & & $\begin{array}{r}\mathrm{O} \\
\text { jgor } \\
\mathrm{Z}\end{array}$ & SI & & \\
\hline $\begin{array}{l}\text { 1. Ocena zgodności kierunków i programów kształcenia } \\
\text { z misją Uczelni }\end{array}$ & 1 & 2 & 3 & 4 & 5 \\
\hline $\begin{array}{l}\text { 2. Ocena zgodności koncepcji kształcenia z celami okre- } \\
\text { ślonymi w strategii Uczelni oraz strategii Wydziału }\end{array}$ & 1 & 2 & 3 & 4 & 5 \\
\hline $\begin{array}{l}\text { 3. Ocena zgodności programów kształcenia } \\
\text { z wymaganiami Krajowych Ram Kwalifikacji }\end{array}$ & 1 & 2 & 3 & 4 & 5 \\
\hline $\begin{array}{l}\text { 4. Ocena zgodności kształcenia z koncepcją rozwoju } \\
\text { kierunku }\end{array}$ & 1 & 2 & 3 & 4 & 5 \\
\hline 5. Ocena doskonalenia systemu punktowego ECTS & & 2 & 3 & 4 & 5 \\
\hline $\begin{array}{l}\text { 6. Ocena postępowania po badaniu opinii studentów na } \\
\text { temat obciążenia pracą własną }\end{array}$ & 1 & 2 & 3 & 4 & 5 \\
\hline $\begin{array}{l}\text { 7. Ocena wykorzystania wyników monitorowania karier } \\
\text { absolwentów w doskonaleniu programów kształcenia }\end{array}$ & 1 & 2 & 3 & 4 & 5 \\
\hline $\begin{array}{l}\text { 8. Ocena zaangażowania przedstawicieli pracodawców } \\
\text { w tworzenie programu kształcenia oraz doskonalenie } \\
\text { programu kształcenia }\end{array}$ & 1 & 2 & 3 & 4 & 5 \\
\hline $\begin{array}{l}\text { 9. Ocena zgodności programów kształcenia z potrzebami } \\
\text { rynku pracy }\end{array}$ & 1 & 2 & 3 & 4 & 5 \\
\hline $\begin{array}{l}\text { 10. Ocena infrastruktury dydaktycznej, w tym dostępu do } \\
\text { literatury zalecanej w ramach kształcenia na kierunku } \\
\text { studiów }\end{array}$ & 1 & 2 & 3 & 4 & 5 \\
\hline $\begin{array}{l}\text { 11. Ocena publicznego dostępu do aktualnych } \\
\text { i obiektywnie przedstawionych informacji o progra- } \\
\text { mach studiów, zakładanych efektach kształcenia, orga- } \\
\text { nizacji i procedurach w toku studiów }\end{array}$ & 1 & 2 & 3 & 4 & 5 \\
\hline $\begin{array}{l}\text { 12. Ocena rzetelności i aktualności informacji o efektach } \\
\text { dla programu kształcenia oraz metodach sprawdzania } \\
\text { i oceny efektów }\end{array}$ & 1 & 2 & 3 & 4 & 5 \\
\hline $\begin{array}{l}\text { 13. Ocena doskonalenia programów kształcenia po wyni- } \\
\text { kach ankiet studenckich }\end{array}$ & 1 & 2 & 3 & 4 & 5 \\
\hline $\begin{array}{l}\text { 14. Ocena zgodności realizacji procesu dydaktycznego } \\
\text { z założeniami programu oraz przepisami wewnątrzu- } \\
\text { czelnianymi }\end{array}$ & 1 & 2 & 3 & 4 & 5 \\
\hline \multirow{2}{*}{ Ile ocen } & & & & & \\
\hline & $\mathrm{a}$ & $b$ & $\mathrm{c}$ & d & $\mathrm{e}$ \\
\hline
\end{tabular}

Źródło: Opracowanie własne

Oceniając kryteria w skali od 1 do 5, można następnie, podstawiając do wzoru (5), obliczyć jakość programu kształcenia. 


$$
H=\frac{9 a+7 b+4 c+2 d+e-14}{112}+\frac{c+5 d+10 e}{2800}-0,05
$$

Wyniki oceny jakości programu kształcenia umożliwiają porównywanie między programami, ale i mogą być też podstawą do wykazywania potrzeb doskonalenia tych programów.

\section{Podsumowanie}

Doskonalenie programów kształcenia wydaje się być koniecznością, gdy uczelnie wyższe chcą sprostać oczekiwaniom studentów. Dobrym sposobem skutecznego ich dopasowywania do zmieniającego otoczenia może być ich liczbowa ocena. Jedną z metod, jaką można dokonać ich oceny, jest punktacja sformalizowana. Dla wybranych kryteriów oceny uwidacznianych dzisiaj często w postaci zagadnień do opisania należałoby dodać ocenę każdego kryterium w skali: 1 (najgorzej) $\div 5$ (najlepiej). Następnie, korzystając z metodyki punktacji sformalizowanej, należałoby wyliczyć aktualną jakość programu. Jakość policzona po kolejnym roku akademickim mogłaby być porównywana do wcześniej wyliczonej. Poprzez to możliwym byłoby określenie rzeczywistego doskonalenia programów kształcenia.

Publikacja nie wyczerpuje tematu tego istotnego zagadnienia. Nie udzielono też odpowiedzi na nasuwające się pytania i nie wyjaśniono wielu wątpliwości. Niektóre $\mathrm{z}$ nich pojawią się być może dopiero w później fazie ocen programów kształcenia, wraz z nabywaniem doświadczeń. Autorzy mają jednak nadzieję, że zaprezentowana metodyka będzie pomocna i będzie dobrze służyć środowisku akademickiemu.

\section{Literatura}

1. Kraśniewski A. (b.r.), Projekt Ministerstwa Nauki i Szkolnictwa Wyższego „Krajowe Ramy Kwalifikacji w Szkolnictwie Wyższym jako Narzędzie Poprawy Jakości Kształcenia”, http://www.procesbolonski.uw.edu.pl/.../publikacja_MNISW_AK_111103.pdf (dostęp: 11.01.2016).

2. Pacana A., Ostasz G. (2015), Narzędzia zarządzania jakością w analizie i ocenie jakości kształcenia, [w:] Stawicki R. (red.), Dydaktyka zawodowa. Dylematy i wyzwania, Wydział Wydawnictw i Poligrafii Centrum Szkolenia Policji w Legionowie, Legionowo.

3. Pacana A. (2012), Koncepcja ankietowego badania jakości procesów dydaktycznych, Recenzovaný zborník vedeckých prác k riešeniu projektov MVP č. 23320262, 2330263, 2330264, „PERFECT (PERFormance \& EffiCiencyIndicaTors)” „Uplatnenie inovatívnych metód vo výučbe manažérskych a ekonomických disciplín II”, „Európska únia na ceste k ciel’u stratégie Európa 2020” Ekonomická Univerzita v Bratislave, Podnikovohospodárska Fakulta v Košiciach, Košicie, s. 72-80.

4. Pacana A., Sęp J., Zielecki W. (2011), Ocena jakości usług dydaktycznych na przykładzie studiów podyplomowych. Komputerowo zintegrowane zarządzanie, Oficyna Wydawnicza Polskiego Towarzystwa Zarządzania Produkcją, Opole.

5. Sęp J., Perłowski R., Pacana A. (2006), Techniki wspomagania zarządzania jakością, Oficyna Wydawnicza Politechniki Rzeszowskiej, Rzeszów. 
6. Zatwarnicka-Madura B. (2011), Wybrane aspekty promocji szkół wyższych na przykładzie Politechniki Rzeszowskiej, [w:] Cyfert Sz., Kochalski C. (red.), Projektowanie i wdrażanie strategii rozwoju w publicznych szkołach wyższych w Polsce - aspekty teoretyczne i praktyczne, Zeszyty Naukowe, nr 167, Wydawnictwo Uniwersytetu Ekonomicznego w Poznaniu, Poznań.

7. Zimon D. (2015), Impact of the Implementation of Quality Management System on Operating Cost for Small and Medium-Sized Business Organizations Affiliated to a Purchasing Group, "International Journal for Quality Research”, Vol. 9(4).

\title{
THE CONCEPT OF QUALITY ASSESSMENT FOR EDUCATIONAL PROGRAMS
}

\begin{abstract}
The high quality of educational process is the desired value for each university. Proper educational programs increase the probability of achieving by students the assumed learning outcomes. These in turn increase the chances of graduates for satisfactory job and professional career. To meet this role educational programs must be improved to match the constantly changing environment. To determine the directions of improvements these programs have to be reviewed first. Mostly this overview ends with the alternative concluding assessment. It seems to be appropriate to introduce a numerical evaluation of the program quality. This study proposes to carry out an assessment with the method of formalized scores.
\end{abstract}

Keywords: educational program, formalized scores, education quality 